\title{
Patelloplasty with and without circumpatellar denervation in reducing anterior knee pain in primary total knee arthroplasty: a comparative prospective study
}

\author{
Sandeep Kumar Kanugula, Mallesh Rathod*, Venugopal S. M.
}

\begin{abstract}
Department of Orthopedics, BIRRD (T) Hospital, Sri Padmavathi Medical College for Women, SVIMS, Tirupati, Andhra Pradesh, India
\end{abstract}

Received: 20 December 2019

Revised: 06 January 2020

Accepted: 07 January 2020

*Correspondence:

Dr. Mallesh Rathod,

E-mail: drmalleshrathod@gmail.com

Copyright: () the author(s), publisher and licensee Medip Academy. This is an open-access article distributed under the terms of the Creative Commons Attribution Non-Commercial License, which permits unrestricted non-commercial use, distribution, and reproduction in any medium, provided the original work is properly cited.

\begin{abstract}
Background: Anterior knee pain (AKP) following total knee arthroplasty (TKA) is one of the complication which cause dissatisfaction in patients. Incidence estimated to be 4-49\%. The aim of our study is to know the efficacy of patelloplasty with circumpatellar denervation with diathermy in reducing AKP in primary TKA.

Methods: A total of 130 unilateral TKAs' are divided into 2 groups. Group I (control) includes 65 patients in which only patelloplasty was done. Group II (intervention) includes 65 patients in which both patelloplasty and circumpatellar denervation with diathermy was done and analysed. Mean follow up period was 18 months. Patients were assessed both preoperatively and postoperatively at final follow up.

Results: The overall incidence of AKP at follow up (18 months) was $16.9 \%$, with $7.7 \%$ in the intervention group and $26.1 \%$ in the control group $(\mathrm{p}<0.05)$. Western Ontario and McMaster Universities osteoarthritis index scores were significantly better in intervention group when compared to control group $(28.71 \pm 3.948$ vs $31.40 \pm 3.860)$. Better results were also found in knee society scores for intervention group compared to control group (166.57 \pm 7.941 vs $161.23 \pm 11.219$ ); Feller patellar score of intervention group was significantly better when compared to control group $(23.28 \pm 2.546$ vs $20.69 \pm 3.729)$; the range of knee flexion was similar in both the groups $(94.62 \pm 12.6$ vs $93.54 \pm 10.7)$. In terms of pain referred by the patient at $72 \mathrm{hrs}$ postoperatively, there was statistically significant difference observed according to visual analogue scale.

Conclusions: There is statistically significant difference with respect to AKP in patients who have undergone patelloplasty with circumpatellar denervation using diathermy compared with patelloplasty alone.
\end{abstract}

Keywords: Total knee arthroplasty, Anterior knee pain, Patelloplasty, Circumpatellar denervation, Diathermy, Range of motion

\section{INTRODUCTION}

Total knee arthroplasty (TKA) is one of the most successful surgical procedure with over $90 \%$ survival rate at 10-15 year. ${ }^{1-4}$ It provides a stable, pain free range of motion (ROM) which improves quality of life. Anterior knee pain (AKP) following TKA is one of the complication which cause dissatisfaction in patients. Incidence estimated to be $4-49 \% .{ }^{5-10} \mathrm{AKP}$ may be related to a number of factors like degree of wear of the patellar cartilage (chondropathy), patellofemoral maltracking, prosthetic design, patient selection, operative technique used, peripatellar soft tissues (retinaculum and 
synovium), infrapatellar fat pad, and the use of patellar resurfacing. $5,6,7,11-20$

Many authors reported that the AKP is due to substance$P$ nociceptive afferent fibers in the peripatellar soft tissues. ${ }^{21}$ Denervation of these nerve fibers around the patella by diathermy have been used for treatment of anterior knee pain in TKA. ${ }^{15,22-25}$ The purpose our study is to know the efficacy of patelloplasty with circumpatellar denervation in reducing anterior knee pain in TKA.

\section{METHODS}

This is a prospective study that was carried out in BIRRD (T) Hospital, Tirupati, Andhra Pradesh, India between January 2018 to October 2019. Patients were followed up to 18 months. A total of 150 unilateral TKA's were included in our study which were divided into 2 groups. Group I (control) which include 75 patients in which patelloplasty alone (Figure 1) was done of which 9 patients were lost to follow up. Group II (intervention) includes 75 patients in which both patelloplasty and circumpatellar denervation with diathermy (Figure 2) was done of which 8 patients were lost to follow up. For calculation purpose we have considered only 65 patients in each group and were analysed.

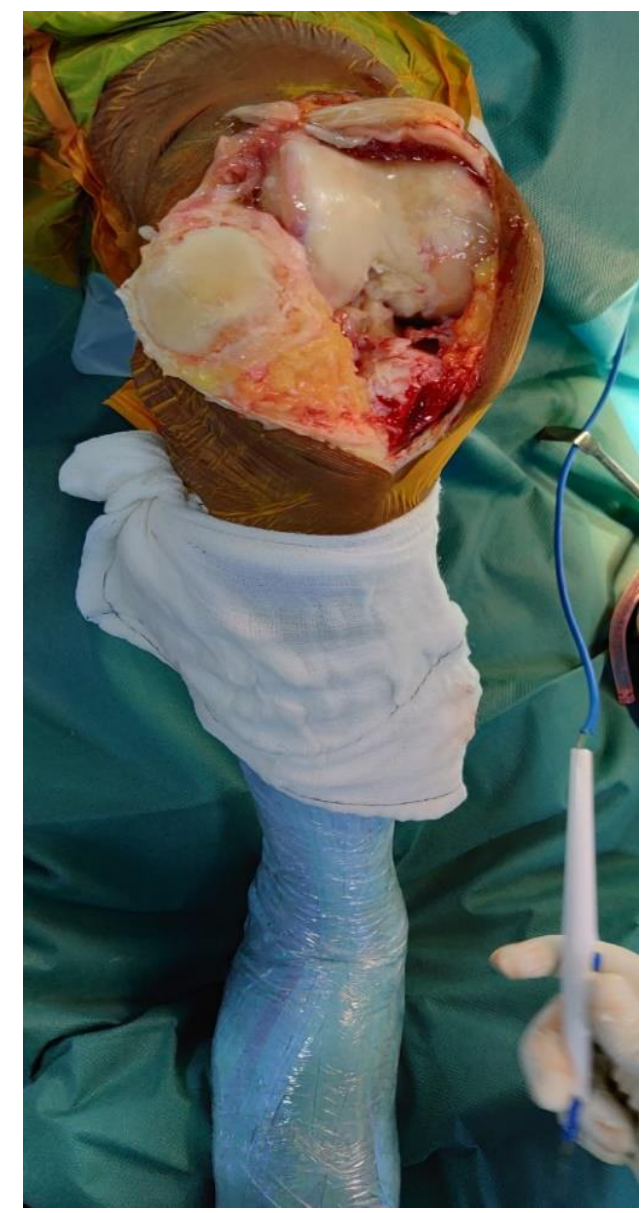

Figure 1: Intraoperative image after patelloplasty alone.

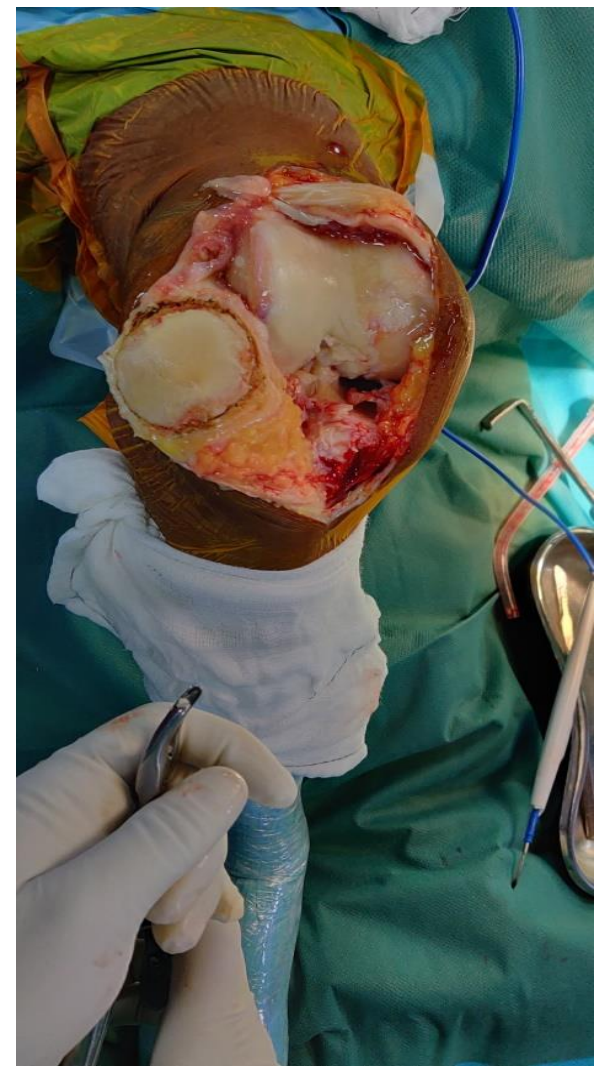

Figure 2: Intraoperative image after patelloplasty with circumpatellar denervation with diathermy.

\section{Inclusion criteria}

Patients with primary osteoarthritis, patients between 40 to 80 years, patients undergoing TKA and minimum follow up of 18 months at the time of evaluation.

\section{Exclusion criteria}

Patients with previous history of patellar fracture and patella surgery, patients who have undergone high tibial osteotomy and distal femoral osteotomy, patients with inflammatory arthritis, revision total knee replacement and patients who did not give consent for surgery.

TKA was performed by one of the four surgeons using PFC Sigma (Depuy) and Optetrak (Exactech) posteriorstabilised fixed-bearing implants. After tourniquet inflated all knees exposed with standard medial parapatellar approach. Patella everted, partial fat pad excision done for better visualization of lateral tibial plateau. Proximal tibial cut was performed perpendicular to tibial mechanical axis. Distal femoral cut with $5^{\circ}$ valgus and $3^{\circ}$ external rotation with respective to posterior femoral condyles was performed. Damaged to patellar cartilage was assessed using outerbridge grading system. ${ }^{26}$ Patellar osteophytes were removed in all patients. In intervention group circumpatellar denervation with diathermy (set to 60 Watts) to a depth of 1 to $2 \mathrm{~mm}$ was done superior-inferiorly at the insertion of 
quadriceps and origin of patellar tendon respectively and 2 to $3 \mathrm{~mm}$ mediolaterally. Checked for patellar tracking, if patella maltracking occur then a lateral retinacular release is performed at least $2 \mathrm{~cm}$ lateral to the border of the patella. cementing of the femoral and tibial components was done. Wound closed in layers in $40-50^{\circ}$ of knee flexion over suction drain. Patient was mobilized on $1^{\text {st }}$ post op day. Radiographs of both weight bearing anteroposterior, lateral and skyline views were taken. Post op rehabilitation was done for every patient. AKP was assessed using visual analogue scale (VAS) preoperatively and at $72 \mathrm{hrs}$ postoperatively. Knee range of motion, knee society score (KSS), Western Ontario and McMaster Universities osteoarthritis index (WOMAC) and Feller patellar score were evaluated preoperatively and at 18 months post operatively. ${ }^{27-30}$

\section{Statistical analysis}

Preoperative and final follow-up results were used for statistical analysis. We used SPSS 20 software (SPSS $®$ for Windows 16.0, Chicago, IL). Continuous variables were expressed as mean $\pm \mathrm{SD}$. The variable gender was described by absolute and relative frequency, the variables age, BMI, WOMAC, KSS, knee ROM, and VAS were described by mean. Group comparison used independent-samples $\mathrm{t}$-test; pre- and postoperative values were compared by paired-samples $\mathrm{t}$-test. $\mathrm{P}$ value $<0.05$ was considered significant.

\section{RESULTS}

Sixty five patients were allotted in each control and intervention group. Mean age at the time of surgery for control and intervention group was $61.32 \pm 8.65$ yrs and $62.35 \pm 7.89$ yrs respectively. There were 31 males and 34 females in control group; 34 males and 31 females in intervention group. Mean BMI was $27.77 \pm 2.276 \mathrm{~kg} / \mathrm{m}^{2}$ and $27.27 \pm 2.029 \mathrm{~kg} / \mathrm{m}^{2}$ in control and intervention group respectively. There were no statistically significant differences with respective to age, sex and BMI in between both the groups (Table 1). Intraoperative cartilage status of patella (outerbridge grading) also didn't show any difference $(\mathrm{p}>0.05)$ (Table 2$)$.

At 18 months of follow-up, 17 patients in control group and 5 patients in intervention group with a respective incidence of $26.1 \%$ (95\% CI 20-31) and $7.7 \%$ (95\% CI 312) reported $\mathrm{AKP}$, representing an overall incidence of $16.9 \%$ (95\% CI 12-20). There was statistically significant difference between two groups $(\mathrm{p}<0.05)$.

Mean pre-operative and post-operative ROM in control group was $83.9 \pm 10.561^{\circ}$ and $93.54 \pm 10.7^{\circ}$ respectively; Mean pre-operative and post-operative ROM in intervention group was $86.46 \pm 12.302^{\circ}$ and $94.62 \pm 12.6^{\circ}$ respectively. There was no significant difference in ROM both preoperatively and post-operatively. In both groups, KSS and feller patellar score was increased; VAS and WOMAC scores was decreased significantly in postoperative follow-up. Furthermore, on all the parameters, there was a statistically significant difference postoperatively in favour of the intervention group (Table 3).

Three knees, two in the intervention group and one in the control group, showed delayed wound healing on average it took total of 3 weeks for wound healing. In two knees, one in intervention group and another one in the control group showed stiffness $(\mathrm{ROM}<50)$ for which manipulation under anaesthesia was performed to improve flexion after the fourth post-operative week. These patients had obtained $90^{\circ}$ of flexion at 18 months follow up. There were no radiological signs of patellar osteonecrosis.

Table 1: Age, sex, BMI and side distribution $(n=65)$.

\begin{tabular}{|c|c|c|c|}
\hline \multirow{2}{*}{ Variable } & Control group & Intervention group & \multirow[t]{2}{*}{ Statistical significance } \\
\hline & $\mathbf{N}(\%)$ & $\mathbf{N}(\%)$ & \\
\hline \multicolumn{4}{|l|}{ Age group (yrs) } \\
\hline $41-50$ & $11(16.9)$ & $2(3.1)$ & \multirow{4}{*}{$\chi^{2}=7.059^{@} ; \mathrm{p}=0.070 ; \mathrm{df}=3$} \\
\hline $51-60$ & $19(29.2)$ & $24(36.9)$ & \\
\hline $61-70$ & $24(36.9)$ & $26(40.0)$ & \\
\hline$>70$ & $11(16.9)$ & $13(20.0)$ & \\
\hline Mean age \pm SD (yrs) & $61.32 \pm 8.65$ & $62.35 \pm 7.89$ & $\mathrm{t}=0.710^{@} ; \mathrm{p}=0.479(\mathrm{p}>0.05)$ \\
\hline \multicolumn{4}{|l|}{ Sex } \\
\hline Male & $31(47.7)$ & $34(52.3)$ & \multirow{2}{*}{$\chi^{2}=0.277^{@} ; p=0.599 ; \mathrm{df}=1$} \\
\hline Female & $34(52.3)$ & $31(47.7)$ & \\
\hline \multicolumn{4}{|l|}{ BMI $\left(\mathrm{kg} / \mathrm{m}^{2}\right)$} \\
\hline Normal & $8(12.3)$ & $10(15.3)$ & \\
\hline Overweight & $50(76.9)$ & $51(78.5)$ & \\
\hline Obese & $7(10.8)$ & $4(6.2)$ & \\
\hline Mean BMI士SD & $27.77 \pm 2.276$ & $27.27 \pm 2.029$ & $\mathrm{t}=1.321^{@} ; \mathrm{p}=0.189$ \\
\hline Side (right:left) & $39: 26$ & $29: 36$ & $\mathrm{p}>0.05$ \\
\hline
\end{tabular}

@ Not significant. 
Table 2: Outerbridge grading system for patellar cartilage status $(n=65)$.

\begin{tabular}{|lll|}
\hline Outer bridge grading system & Group & P value \\
\hline $\mathbf{0}$ & Control & Intervention \\
\hline $\mathbf{1}$ & 0 & 0 \\
\hline $\mathbf{2}$ & 0 & 1 \\
\hline $\mathbf{3}$ & 11 & 3 \\
$\mathbf{4}$ & 38 & 44 \\
\end{tabular}

p>0.05; not significant.

Table 3: Mean pre-operative and post-operative parameters in control and intervention group $(\mathbf{n}=65)$.

\begin{tabular}{|c|c|c|c|c|c|}
\hline Parameters & Group & Control & Intervention & $\begin{array}{l}\text { Mean } \\
\text { difference }\end{array}$ & P value \\
\hline \multirow{2}{*}{ ROM } & Pre-op flexion & $83.9 \pm 10.561$ & $86.46 \pm 12.302$ & -2.615 & ${ }^{\circledR} \mathrm{P}>0.05$ \\
\hline & Postop flexion & $93.54 \pm 10.7$ & $94.62 \pm 12.6$ & -1.077 & ${ }^{\circledR} \mathrm{P}>0.05$ \\
\hline \multirow{2}{*}{ VAS score } & Pre-operative & $7.95 \pm 0.975$ & $8.54 \pm 0.849$ & -0.59 & $\mathrm{P}<0.001$ \\
\hline & Post-operative (72 hrs) & $1.89 \pm 2.425$ & $0.68 \pm 1.501$ & 1.21 & $\mathrm{P}<0.001$ \\
\hline \multirow{2}{*}{ WOMAC score } & Pre-operative & $68.82 \pm 6.798$ & $68.86 \pm 7.514$ & -0.046 & ${ }^{\circledR} \mathrm{P}>0.05$ \\
\hline & Post-operative & $31.40 \pm 3.860$ & $28.71 \pm 3.948$ & 2.692 & $\mathrm{P}<0.001$ \\
\hline \multirow{2}{*}{ KSS } & Pre-operative & $27.88 \pm 8.728$ & $25.26 \pm 7.081$ & 2.615 & ${ }^{\circledR} \mathrm{P}>0.05$ \\
\hline & Post-operative & $161.23 \pm 11.219$ & $166.57 \pm 7.941$ & -5.338 & $\mathrm{P}<0.001$ \\
\hline \multirow{2}{*}{$\begin{array}{l}\text { Feller patellar } \\
\text { score }\end{array}$} & Pre-operative & $11.45 \pm 2.784$ & $11.54 \pm 2.257$ & -0.092 & ${ }^{\circledR} \mathrm{P}>0.05$ \\
\hline & Post-operative & $20.69 \pm 3.729$ & $23.28 \pm 2.546$ & -2.585 & $\mathrm{P}<0.001$ \\
\hline
\end{tabular}

**p $<0.001$ significant; @ Not significant.

\section{DISCUSSION}

AKP following TKA is one of the complication which cause dissatisfaction in patients. It has been evaluated in a number of studies by different authors but many aspects of AKP after TKA yet to be furthermore analysed. Etiology of AKP is multifactorial, which may be due to wear of the patellar cartilage, inflammation of peripatellar soft tissues (retinaculum and synovium), impingement of infra patellar fat pad, surface incongruities (patellofemoral maltracking), prosthetic design and operative technique used. Different procedures were used for prevention and treatment of AKP after TKA which includes patelloplasty alone, patelloplasty with circumpatellar denervation, lateral retinacular release or patellar resurfacing but their effectiveness is still debatable. Cemil et al did a prospective study on 46 patients (49 knees), performed patelloplasty alone and followed for an average of 41.1 months. They noticed improvement in postoperative KSS and Feller patellar score. This study concluded that, patelloplasty in TKA is an option for the reduction of AKP. ${ }^{31}$ Wang et al also conducted a retrospective study with 132 patients, did patelloplasty alone in all the patients and followed up for a mean of 7.8 years. There was improvement in postoperative KSS and patellar score. Author stated that, the patellar retention with a patelloplasty may be better option even in knees with advanced patellofemoral arthritis. ${ }^{32}$ Krompinger and Fulkerson reported that lateral retinacular release is indicated in patients with AKP. ${ }^{33}$ But Witonski and Wagrowska- Danielewicz stated that substance-P positive fibers appear to be more prevalent in the fat pad and medial retinaculum. They concluded that lateral retinacular release was not as effective as expected. ${ }^{34}$ Maralcan et al stated that the patella has two nerve supplies, passing within the substance of the vastus medialis and lateralis in superomedial and superolateral quadrants respectively. Denervation of these nerves and their branches to be performed to prevent postoperative AKP. ${ }^{35}$ So in our study we performed both patelloplasty and circumpatellar denervation among patients who have undergone TKA to know its efficacy. Altay et al performed a randomized control study in 2012 which included 35 knees each in intervention and control group. They reported that there is a definite advantage with patellar denervation. ${ }^{36}$ In a study conducted by Balinga et al the outcome following circumpatellar denervation was assessed based on oxford knee score (OKS) and AKP using VAS. This study showed statistically significant improvement in the OKS and VAS among the patella denervation group. ${ }^{37}$ Jonberger performed a study in 2008 which included 131 patients in each control (no denervation) and intervention (denervation) group followed for a period of 1 year. They showed that patellar denervation using electrocautery improves the outcome. The intervention group had a better WOMAC score (16.3 vs 21.6, p value 0.04). Knee society score (92.4 vs 90.4, p value 0.14 ) was similar in both the group. ${ }^{38}$ But a randomized control trial conducted by the same author showed that the initial clinical improvement with electrocautery denervation of patella in TKA is not maintained at a mean follow up of 3.7 years. ${ }^{39}$ In a metaanalysis conducted by Cheng et al reported that there is no strong evidence either for or against circumpatellar 
denervation with electrocautery compared with no denervation in TKA. ${ }^{40}$ In our study we therefore performed patelloplasty with circumpatellar denervation and observed that postoperative knee ROM,VAS, KSS, WOMAC and Feller patellar score were significantly better in the denervation group. These findings indicate that patellar denervation by diathermy decreases AKP and improves clinical outcome after TKA without patellar resurfacing. Limitations in our study are small sample size, patients operated by multiple surgeons, use of different implant designs and short follow-up duration.

\section{CONCLUSION}

There is a statistically significant difference between final outcome of patients who underwent patella denervation using circumpatellar diathermy and those without denervation with respect to AKP among patients who have undergone TKA. Further larger long-term prospective comparative series are needed to support these results.

Funding: No funding sources Conflict of interest: None declared

Ethical approval: The study was approved by the institutional ethics committee

\section{REFERENCES}

1. Ranawat CS, Padgett DE, Ohashi Y. Total knee arthroplasty for patients younger than55 years. Clin Orthop Relat Res. 1989;248:27-33.

2. Rand JA, Trounsdale RT, Ilstrup DM, Harmsen WS. Factors affecting the durability of primary total knee prostheses. J Bone Joint Surg Am. 2003;85(2):25965.

3. Scuderi GR, Insall JN, Windsor RE, Moran MC. Survivorship of cemented knee replacements. J Bone Joint Surg Br. 1989;71(5):798-803.

4. Gioe TJ, Killeen KK, Grimm K, Mehle S, Scheltema K. Why are total knee replacements revised?Analysis of early revision in a community knee implant registry. Clin Orthop Relat Res. 2004;428:100-6.

5. Wood DJ, Smith AJ, Collopy D, White B, Brankov B, Bulsara MK. Patellar resurfacing in total knee arthroplasty: a prospective, randomized trial. J Bone Joint Surg Am. 2002;84:187-93.

6. Waters TS, Bentley G. Patellar resurfacing in total knee arthroplasty. A prospective, randomized study. J Bone Joint Surg Am. 2003;85:212-7.

7. Popovic N, Lemaire R. Anterior knee pain with a posteriorstabilized mobile bearing knee prosthesis: the effect of femoral component design. J Arthroplasty. 2003;18:396-400.

8. Burnett RS, Haydon CM, Rorabeck $\mathrm{CH}$, Bourne RB. Patella resurfacing versus nonresurfacing in total knee arthroplasty: results of a randomized controlled clinical trial at a minimum of 10 years follow up. Clin Orthop Relat Res. 2004;428:12-25.
9. Burnett RS, Boone JL, McCarthy KP, Rosenzweig $\mathrm{S}$, Barrack RL. A prospective randomized clinical trial of patellar resurfacing and non-resurfacing in bilateral TKA. Clin Orthop Relat Res. 2007;464:65-72.

10. Smith AJ, Wood DJ, Li MG. Total knee replacement with and without patellar resurfacing: a prospective, randomised trial using the profix total knee system. J Bone Joint Surg Br. 2008;90:43-9.

11. Mori Y, Kuroki Y, Yamamoto R, Fujimoto A, Okumo H, Kubo M. Clinical and histological study of patellar chondropathy in adolescents. Arthroscopy. 1991;7:182-97.

12. Wilson NA, Press JM, Koh JL, Hendrix RW, Zhang LQ. In vivo noninvasive evaluation of abnormal patellar tracking during squatting in patients with patellofemoral pain. J Bone Joint Surg (Am). 2009;91:558-66.

13. Skwara A, Tibesku CO, Ostermeier S, StukenborgColsman C, Fuchs-Winkelmann S. Differences in patellofemoral contact stresses between mobile bearing and fixed-bearing total knee arthroplasties: a dynamic in vitro measurement. Arch Orthop Trauma Surg. 2008;129:901-7.

14. Breugem SJ, Sierevelt IN, Schafroth MU, Blankevoort L, Schaap GR, van Dijk CN. Less anterior knee pain with a mobile-bearing prosthesis compared with a fixed bearing prosthesis. Clin Orthop Relat Res. 2008;466:1959-65.

15. Barrack RL, Burak C. Patella in total knee arthroplasty. Clin Orthop Relat Res. 2001;389:62-73.

16. Smith AJ, Lloyd DG, Wood DJ. Pre-surgery knee joint loading patterns during walking predict the presence and severity of anterior knee pain after total knee arthroplasty. J Orthop Res. 2004;22:260-6.

17. Fern ED, Winson IG, Getty CJ. Anterior knee pain in rheumatoid patients after total knee replacement. Possible selection criteria for patellar resurfacing. J Bone Joint Surg Br. 1992;74:745-8.

18. Lehner B, Koeck FX, Capellino S, Schubert TE, Hofbauer R, Straub RH. Preponderance of sensory versus sympathetic nerve fibers and increased cellularity in the infrapatellar fat pad in anterior knee pain patients after primary arthroplasty. J Orthop Res. 2008;26:342-50.

19. Maculé F, Sastre S, Lasurt S, Sala P, Segur JM, Mallofré C. Hoffa's fat pad resection in total knee arthroplasty. Acta Orthop Belg. 2005;71:714-7.

20. Cameron HU. Comparison between patellar resurfacing with an inset plastic button and patelloplasty. Can J Surg. 1991;34:49-52.

21. Wojtys EM, Beaman DN, Glover RA, Janda D. Innervation of the human knee joint by substance-P fibers. Arthroscopy. 1990;6:254-63.

22. Keblish PA, Varma AK, Greenwald AS. Patellar resurfacing or retention in total knee arthroplasty. A prospective study of patients with bilateral 
replacements. J Bone Joint Surg (Br). 1994;76:930-7.

23. Pellengahr C, Maier M, Müller PE, Dürr HR, Schulz C, Zysk S, et al. Surgical and anatomic parameters influencing femoropatellar pain in total knee arthroplasty. Eur J Trauma. 2002;28:242-6.

24. Kim TH, Lee DH, Bin SI. The NexGen LPS-flex to the knee prosthesis at a minimum of three years. J Bone Joint Surg (Br). 2008;90:1304-10.

25. van Hemert WL, Senden R, Grimm B, Kester AD, van der Linde MJ, Heyligers IC. Patella retention versus replacement in total knee arthroplasty; functional and clinimetric aspects. Arch Orthop Trauma Surg. 2009;129:259-65.

26. Outerbridge RE. The etiology of chondromalacia patellae. J Bone Joint Surg [Br]. 1961;43-B:752-7.

27. McCormack HM, Horne DJ, Sheather S. Clinical applications of visual analogue scales: a critical review. Psychol Med. 1988;18:1007-19.

28. Insall JN, Dorr LD, Scott RD, Scott WN. Rationale of the Knee Society clinical rating system. Clin Orthop. 1989;248:13-4.

29. Roorda LD, Jones CA, Waltz M, Lankhorst GJ, Bouter LM, van der Eijken JW, et al. Satisfactory cross-cultural equivalence of the Dutch WOMAC in patients with hip osteoarthritis waiting for arthroplasty. Ann Rheum Dis. 2004;63:36-42.

30. Feller JA, Bartlett RJ, Lang DM. Patellar resurfacing versus retention in total knee arthroplasty. J Bone Joint Surg Br. 1996;78(2):226-8.

31. Cemil E, Mehmet AA, Ugur EI. Patelloplasty with patellar decompression to relieve anterior knee pain in total knee arthroplasty. Acta Orthop Traumatol Turc. 2011;45(6):425-30.

32. Hwang $\mathrm{BH}$, Yang $\mathrm{IH}$, Han CD. Comparison of patellar retention versus resurfacing in LCS mobilebearing total knee arthroplasty. Knee Surg Sports Traumatol Arthrosc. 2012;20:524-31.

33. Krompinger WJ, Fulkerson JP. Lateral retinacular release for intractable lateral retinacular pain. Clin Orthop Relat Res. 1983;179:191-3.
34. Witonski D, Wagrowska-Danielewicz M. Distribution of substance-P nerve fibers in the knee joint in patients with anterior knee pain syndrome. A preliminary report. Knee Surg Sports Traumatol Arthrosc. 1999;7:177-83.

35. Maralcan G, Kuru I, Issi S, Esmer AF, Tekdemir I, Evcik D. The innervation of patella: anatomical and clinical study. Surg Radiol Anat. 2005;27:331-5.

36. Altay MA, Ertürk C, Altay N, Akmeşe R, Işıkan UE. Patellar denervation in total knee arthroplasty without patellar resurfacing: a prospective, randomized controlled study. Orthop Traumatol Surg Res. 2012;98(4):421-5.

37. Balinga CJ, McNair KJ, Barnett J, MacLeod RW, Humphry D. Does circumpatellar electrocautery improve the outcome after total knee replacement? A prospective, randomised, blinded controlled trials. Finlayson. J Bone Joint Surg Br. 2012;94B:1228-33.

38. van Jonbergen HPW, Scholtes VAB, van Kampen A, Poolman RW. A randomised, controlled trial of circumpatellar electrocautery in total knee replacement without patellar resurfacing. J Bone Joint Surg [Br]. 2011;93:1054-9.

39. van Jonbergen HPW, Scholtes VA, Poolman RW. A randomised, controlled trial of circumpatellar electrocautery in total knee replacement without patellar resurfacing: a concise follow-up at a mean of 3.7 years. Bone Joint J. 2014;96(4):473-8.

40. Cheng T, Zhu C, Guo Y, Shi S, Chen D, Zhang X. Patellar denervation with electrocautery in total knee arthroplasty without patellar resurfacing: a meta-analysis. Knee Surg Sports Traumatol Arthrosc. 2014;22(11):2648-5.

Cite this article as: Kanugula SK, Rathod M, Venugopal SM. Patelloplasty with and without circumpatellar denervation in reducing anterior knee pain in primary total knee arthroplasty: a comparative prospective study. Int J Res Orthop 2020;6:270-5. 